\title{
Gender Equality in Feminine Registers Used by Female Parents in Blitar: A Case Study of Local Wisdom of Addressing among Women with Respect to their Husbands' Titles
}

\author{
${ }^{1}$ Bagus Waluyo, ${ }^{2}$ Ali Mustofa \\ State University of Surabaya, Lidah Wetan Street, Lidah Wetan, Kec. Lakarsantri, \\ Surabaya, Indonesia
}

Email: 1bagus.19003@mhs.unesa.ac.id, ${ }^{2}$ alimustofa@unesa.ac.id

\begin{tabular}{l}
\hline Available Online: \\
\hline http://www.jurnal.unublitar.ac.id/ \\
index.php/briliant
\end{tabular}

History of the Article:

Received on February 2021

Accepted on May 2021

Published on May 2021

Pages 277-289

\begin{tabular}{l}
\hline Keywords: \\
\hline Local wisdom; gender equality; \\
female; parent; oral tradition \\
\hline DOI: \\
\hline http://dx.doi.org/10.28926/briliant \\
.v3i4.605 \\
\hline
\end{tabular}

\begin{abstract}
The theoretical framework used in the present form is Gender Construction in content analysis. The research observed two hundred selected female parents who have practiced mixed calling among male and female genders. The Data were collected using interviews and recordings carried out through online discussion during female parental activities of the home financial industry $[\mathrm{PKK}]$. The analysis revealed that during the interaction among female parents, they addressed each other's name by mentioning their husbands' names for several reasons: 1) a lack of selfconfidence which is influenced by their habits of always glorifying their husbands in all their activities, 2) Javanese culture in the city of Blitar still binds them, and It is complicated to get rid of it, 3) most of the mothers still have lower occupational education than their husbands, and 4) they are more respected by others if the husband's name is always attached to every activity.
\end{abstract}

\section{INTRODUCTION}

Blitar is a small city located in the province of East Java, Indonesia. Since the independence era until now, the people still believe in local wisdom such as everyday life, he said, recognition of the more exalted degree of man, and many more that are still sacred. It is because Javanese Culture is still attached to their entire life so that non-Javanese culture that enters will experience severe obstacles. Paradoxically while ethnic and regional secession recurrently threatens national unity, indigenous cultures provide a repository of traditions and symbols that the political leaders and the national elite can use to forge a national identity and foster a sense of community (Dahles, 2001). There are quality dealings in the Islamic society's high-power structure because the churchgoing body is comfort submissive by men patch women are advised as a supporter and meagerly groups (Mufidah, 2017). Individual ascendance of females withal relic universal regularize in the most progressive elected commonwealth states.the common assumption legitimizes that structure reflects the presence of God settled by (Ernest, 1985) and (Smith \& Weisstub, 2016). Women consistently reported lower power motivation than men (Schuh et al., 2014). This is in line with the difficulty of recognizing gender equality or the struggle for feminism, especially in the 
activities of the PKK women's group, because they still often glorify their husband as the dignity of the family.

On the other hand, their struggle to equalize gender equality according to the battle of the initiators of feminism is decisive. The debate between local culture and their notions of feminism has caused polemic until now. Therefore this research is fundamental to find new perspectives and solutions to these problems. The combination of Language and Gender is the central concept in this study because the researchers observe the problem phenomenon towards recognizing gender equality in the patterns of oral tradition / spoken language that occur.

From the urgency of the problems mentioned above, the researchers have a strong desire to find out the source of the main issue, which is formulated as follows: what is the leading cause of the confusion of choosing between local wisdom or recognition of gender equality in spoken language addressing among women with respect to their husbands' titles in their activities?

The benefits expected from the results of this study are 1) a new perspective on problem-solving of gender recognition in regions that still honor their local wisdom, and 2) knowledge of the causes of confusion in recognizing gender equality, especially in the activities of mothers.

Local wisdom belief is all that is stereotypical of the zone, whether it be food, traditions, dances, songs, or rituals. (Yustesia, 2018). Culture is an essential halide of the reference point, as it keeps meanings mysterious from multiple elements of the humanoid universe. Now, the classic interpretation of community is " . . . A historically expressed sequence of purposes articulated in images, a set of conventional conceptions embodied in visual images through which men associate, sustain, and cultivate their knowledge and attitude concerning activity. "It is fundamentally attached to the ideals, ideologies, modes of thought, a distance of nature, and viewpoints accepted by the members of the lodge at every recognized sign, according to leading paleontologists (Buvinić \& Rao Gupta, 1997). Culture is a system of human-made corroborative and arbitrary features, in those as mentioned above, intensified the attribute of amusement and culminated in the fulfillment of the respondents in the biology position. Thus it became shared with those who were capable of interacting together because they had relational contact and existed at the same moment and at the same time. (Samovar, L. A., Porter, R. E., McDaniel, E. R., \& Roy, 2013). Since culture is the center of localized beliefs, which is described as a collection of parental convictions by any concrete classification of entities established in constituent locations, it seems central to what people are in love and esteem. Local reasonableness, in other terms, is an institution and a product of a broader group.

Local wisdom is well characterized as local thoughts inculcated with proprietary wizens considered systematic, literally exalting. The measurable behaviors of the members of the gold component have been embodied and enforced. Local wisdom is a whole thing of ethnic capacity. it is a living principle rooted in the gilded belly, embodied in the ways of a useful text, a form of recounting, of rites and of imposing. (Riyanto, A., Ohoitimur, J., Mulyatno, C. B., $\&$ Madung, 2015). The interaction between culture and communication is seen as reciprocal rather than causal, where culture can affect connectivity but is also established and implemented through connectivity. Having conversations is also

278 BRILIANT: Jurnal Riset dan Konseptual

Volume 6 Number 2, May 2021 
seen as a shaped script that acts as a collective, unifying component. (Martin, J. N., \& Nakayama, 2010)

The conception of sexual preference changed again with the 'mainstreaming' line that followed the Beijing Women's Debate in 1995 and the ratification of the Agreement by Sweden and Finland in 1996. Mainstreaming is associated with the fact that policies on sexual equivalence do not present a participant as home-bound to a near 'ghetto' opportunity, but rather an integrated cross-sectional framework to all policy-making comics. Mainstreaming has the voltage to tactfulness disadvantage (the aim of same-treatment policies) without denying conflict (Rees, 1998). Growing acceptance could prove to be 'revolutionary' and a difference in the organization of sexuality. It is designed to ensure that the consistency against which equivalence is rhythmic is itself subject to sexual discrimination. (Walby, 2001). mainstream-friendly and economic policy is dominated by a 'enunciate money, channel economics' class of the neoliberal send (Dyson, 2000). There is also a problem concerning the mainstream collection: to what degree it focuses on conversion tracking, on systematic litigating on behalf of women, and steps to facilitate conversion in both men and women(Booth \& Bennett, 2002). The hazard of such contentedness in the 'tools' of growing acceptance and the unique impact-distinct in the status of sexualityfighting studies, the racial-proofing of records, and the tracking of sexuality-as contractual targets in and of themselves. However, this explanation of mainstreaming fitted healed with the new forms of concept adoptive solon widely in the politeness of multiethnic policies under the ingenious co-ordination (Rees, 1998). The hair-splitting essence of the direction of the policy-making process behind these two components of reform in the strategy to positioning regulations is beyond that of this publisher, as are great debates as to whether identical instruments can be used to articulate actual different forms of inequality. (Woodward, 2003). Efforts to use someone's rights are meant to resolve the problems of forgathering inequality. It is also likely to assume a broader connection between the ulcerated whim of rights-based anti-discrimination laws and the backdrop of policy-making and price-making. (Schuh et al., 2014).

Oral traditions have been systematically gathered and misrepresented to assign chronology, activity, and ethnic affiliation. Indeed, initially, the importance of learning grammar was substantial in transitional or pre-contact anthropology than in past human cultures, where textual sources were given priority.(HoltReynolds, 1992). Excluding Indweller folklore, non-Western oral beliefs are also imbued with messaging and non-literal elements, as well as 'populated by imaginary beings engaged in incredible happenings. (Mason, 2010). Criticism of the purpose of an objective, impartial anthropology discipline, and numerous studies showing that the archaeological interpretation of the ancient may be vindictive as much as the number of subjectivities, desires and noise connections of the division as the analysis of traditions. In this observe, studies of the part of anthropology inquiry in the design of oral traditions and associated forms of available memory had especially puissant combat (e.g., see contributions to (Graves-Brown, P., Jones, S., and Gamble, 1996); (Kohl, P. L., and Fawcett, 1995); (Kohl, P. L., Kozelsky, M., and Ben-Yehuda, 2007);(Meskell, 1998).

Similarly, urban archaeology is an important area where oral testimony played a crucial role (Karskens, G., and Lawrence, 2003); (Schuyler, 1977). New 
legal structures for social heritage, repatriation, and communication of fragile relics and object term bang have all played a part, requiring archaeologists to continue to engage with oral traditions, particularly on matters of place for people. (Echo-hawk et al., 2013). As oral traditions and archaeology merge to make new insightful narratives, do we not intervene in past anthropology in whether texts are available and whether or not the cultures we research are a rhythm of the neoplanetary system? In this loudness, some scholars think of a secondary body that is at the periphery of what force is conventionally known as traditional anthropology: Specific civilizations tilt art; property band forts; a settlement in Papua New Poultry dating back to about 600 geezer hoods; untimely medieval pictorial emblem mien cross-slab; a vivid history of burial sites; and tourer projects involving imaginary landscapes. Each of these instances, however, expands the principles of past archaeology and oral module to a measurable distance. (Schmidt, 2006).

\section{METHOD}

Gender Construction in the content analysis was used for this study. Content analysis has focused on observing human behaviors and features of the environment in which the action occurs (Borg, M.D., \& Ghall, 2007). Gender construction can be depicted by the study, which focuses on content analysis (Craeynest, 2015), (Sunderland, 2006), (Hartman \& Judd, 1978). People construct their gender status with several signs and signals. It can be from the way they dress, speak, walks, gesture, and a sex category, then become gender status through naming, dress, and the use of other gender markers (Lorber, 1994). Two hundred selected female parents who have the habits of practicing mixed calling among male and female genders were the respondents of this research based on self-selection. The Data were collected using interviews and recordings that were carried out through online discussion within two weeks during female parental activities of the home financial industry [PKK] in Blitar. Data analysis of this content analysis study is based on (Klaus Krippendorff, 2004), which is divided into three stages, as follows:

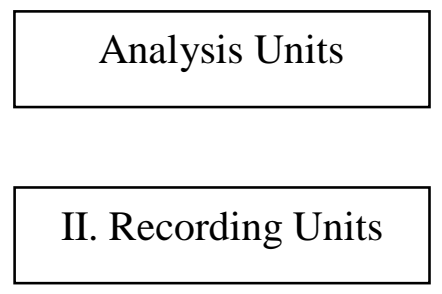

III. Context Units

I. Sampling Units

Figure 1. Unit Analysis for Content Analysis

First, Sampling units are the content of what will be studied, and the content of what is not included in the consideration, and henceforth will not be examined (Eriyanto, 2013). The samples of this study are practicing mixed calling among male and female genders from two hundred selected female parents. They will be identified according to their local wisdom belief, social status, and educational background in a family that can describe certain types of problems from their bias between local wisdom and gender inequality. 
The second one is recording units; recording units are parts of the content that will be recorded, calculated, and analyzed (Eriyanto, 2013). This is related to which part of the content will be recorded, calculated, and analyzed (Eriyanto, 2013). This study is focusing on each practice. This means that codification is based upon a particular theme, in case. Afterward, the data that succeeded from the codification then recorded, calculated, and analyzed. The researchers will estimate and find the problem of confusion.

The last one is the context unit. This unit is used by the researchers to provide context forresearch findings to gain meaning. Once the percentage of practice from a particular theme is achieved, the writer will give sense to the data findings by utilizing gender and discourse interpretation (Eriyanto, 2013). Then the researchers calculate the data about the confusion problem faced by the practice. As a way of answering the questions, they refer (Wienanda, 2012) and (Witjatmoko, 2016) who divide the percentage of the gap into three-stage 0-15\% consider as balance, 16-25\% gap consider to fairly balance, and $>25 \%$ gap is considered as an imbalance. Finally, they category those gaps and interpret as the research finding.

\section{RESULTS AND DISCUSSION}

The findings of the study, which is analyzing gender inequality confusion among female parents, are categorized from 1) local wisdom belief, 2) social status, and 4) educational background. The findings are presented as follows:

Table 1. local wisdom belief

\begin{tabular}{|l|l|l|l|l|l|l|}
\hline Total & belief & \% & practice & $\begin{array}{l}\text { Not } \\
\text { belie } \\
\text { f }\end{array}$ & \% & practice \\
\hline 200 & 149 & 74,5 & $\begin{array}{l}\text { they addressed each } \\
\text { other's name by } \\
\text { mentioning their } \\
\text { husbands' names: a } \\
\text { lack of self-confidence } \\
\text { which is influenced by } \\
\text { their habits of always } \\
\text { glorifying their } \\
\text { husbands in all their } \\
\text { activities and Javanese } \\
\text { Culture in the city of } \\
\text { Blitar still binds them }\end{array}$ & 51 & 25,5 & $\begin{array}{l}\text { they addressed each } \\
\text { other's name by } \\
\text { mentioning their } \\
\text { original name, felt } \\
\text { more familiar when } \\
\text { calling their real } \\
\text { names because they } \\
\text { are used to getting real } \\
\text { names, and no longer } \\
\text { believing in Javanese } \\
\text { customs }\end{array}$ \\
\hline
\end{tabular}

Following the table, it is shown that total participants who believe local wisdom reach 149 as it counts $74,5 \%$ while they who do not believe local wisdom only get 51 as it is on $25,5 \%$. 


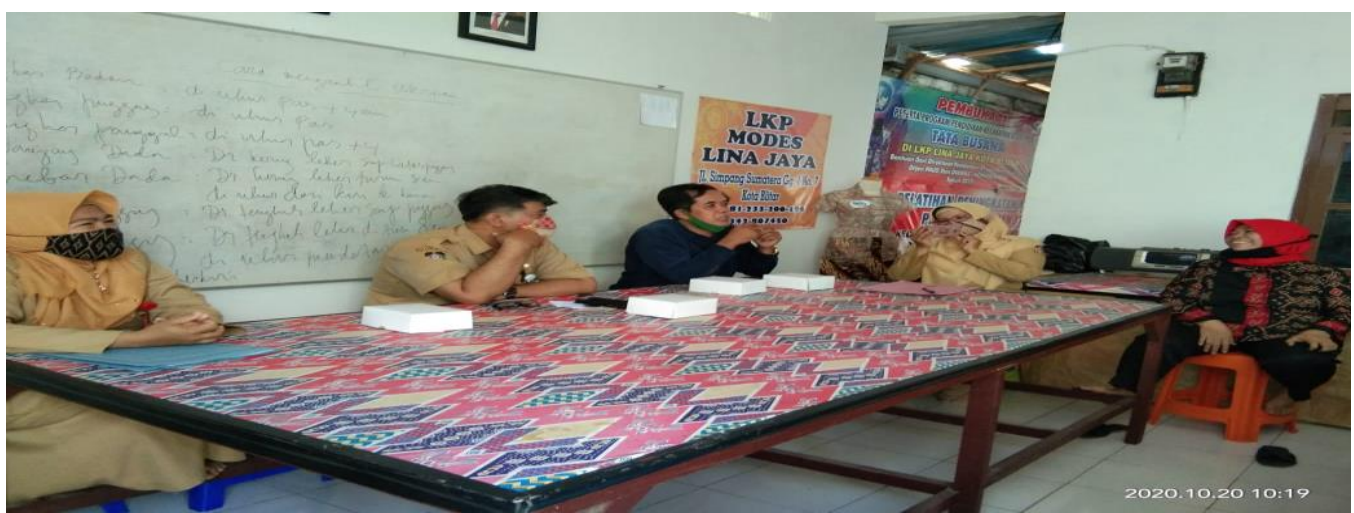

Figure 2. Discussions between ladies and gentlemen in PKK activities from three sub-districts (Sananwetan, kepanjen Kidul, and Sukorejo) in Blitar

The photo above illustrates that the belief in respect for men is still strong because they strongly believe in local wisdom belief since a long time ago even though they work in an equal place.

Table 2. Social status

\begin{tabular}{|l|l|l|l|l|}
\hline $\begin{array}{l}\text { Male } \\
\text { occupation }\end{array}$ & $\begin{array}{l}\text { social } \\
\text { status }\end{array}$ & total & $\%$ & practice \\
\hline $\begin{array}{l}\text { Government } \\
\text { official }\end{array}$ & High level & 91 & $45,5 \%$ & $\begin{array}{l}\text { they are more respected by others if the } \\
\text { husband's name is always attached to } \\
\text { every activity because of their social } \\
\text { Successful } \\
\text { entrepreneur }\end{array}$ \\
\hline $\begin{array}{l}\text { Farmer } \\
\text { Driver } \\
\text { laborer }\end{array}$ & Low level their husband
\end{tabular}

The table has shown that the male occupation in high-level social status reaches 103 as it accounts 51,5\%, on the other hand, the male profession in lowlevel social status gets 97 as it accounts $48,5 \%$ 


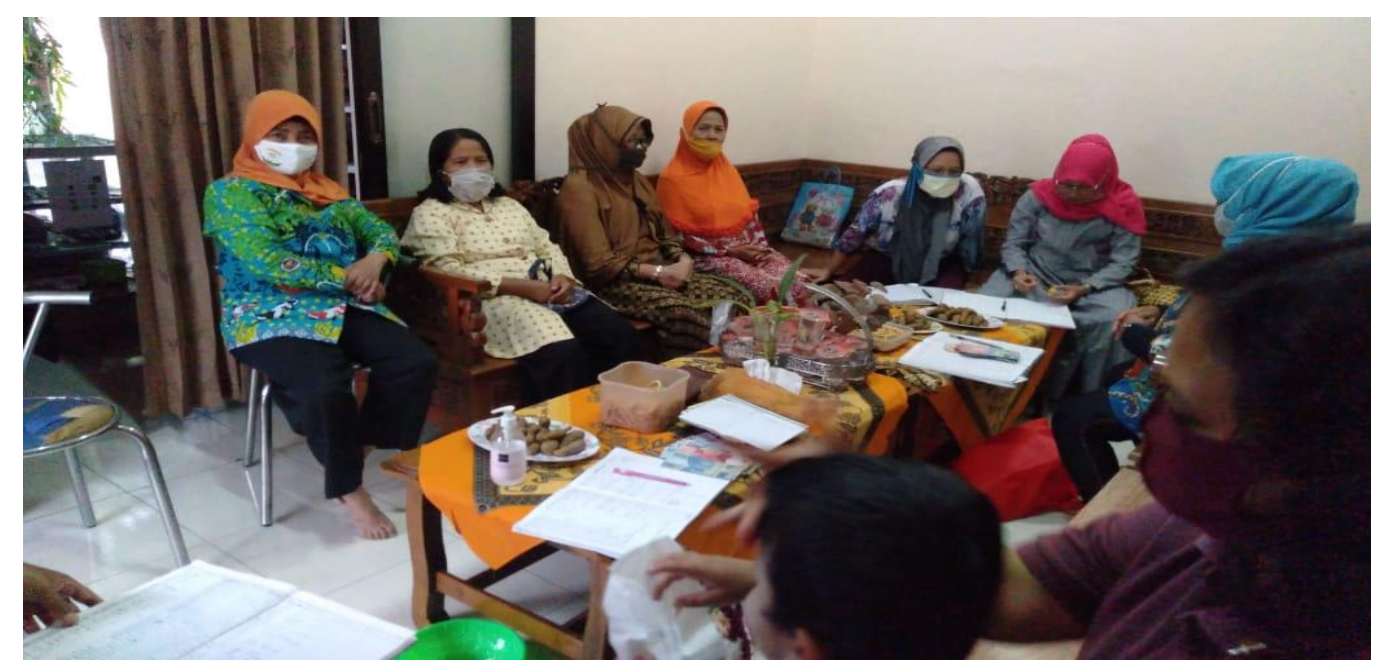

Figure 3. The activities that illustrate the equality between women and men status from Sananwetan District

Table 3. Educational background

\begin{tabular}{|l|l|l|c|l|}
\hline $\begin{array}{l}\text { Educational } \\
\text { background }\end{array}$ & status & total & $\%$ & practice \\
\hline S2 & $\begin{array}{l}\text { High } \\
\text { status }\end{array}$ & 7 & $3,5 \%$ & $\begin{array}{l}\text { They already understand the equality } \\
\text { between men and women, so that the } \\
\text { balance of identity is carried over to all } \\
\text { their activities. }\end{array}$ \\
\hline $\begin{array}{l}\text { Senior High } \\
\text { School }\end{array}$ & $\begin{array}{l}\text { Low } \\
\text { status } \\
\text { Junior high } \\
\text { school } \\
\text { primary } \\
\text { school }\end{array}$ & 109 & $54,5 \%$ & $\begin{array}{l}\text { most of the mothers still have lower } \\
\text { occupational education than their } \\
\text { husbands, so that they always boast of } \\
\text { their husband's identity as a family } \\
\text { authority in their activities, even they } \\
\text { always follow what their parents say } \\
\text { without thinking critically. }\end{array}$ \\
\hline
\end{tabular}

In accordance with the table showing the percentage of Educational background, it is shown that High status reaches 63 as counts 31,5\% while low status gets 137 as counts $68,5 \%$. 


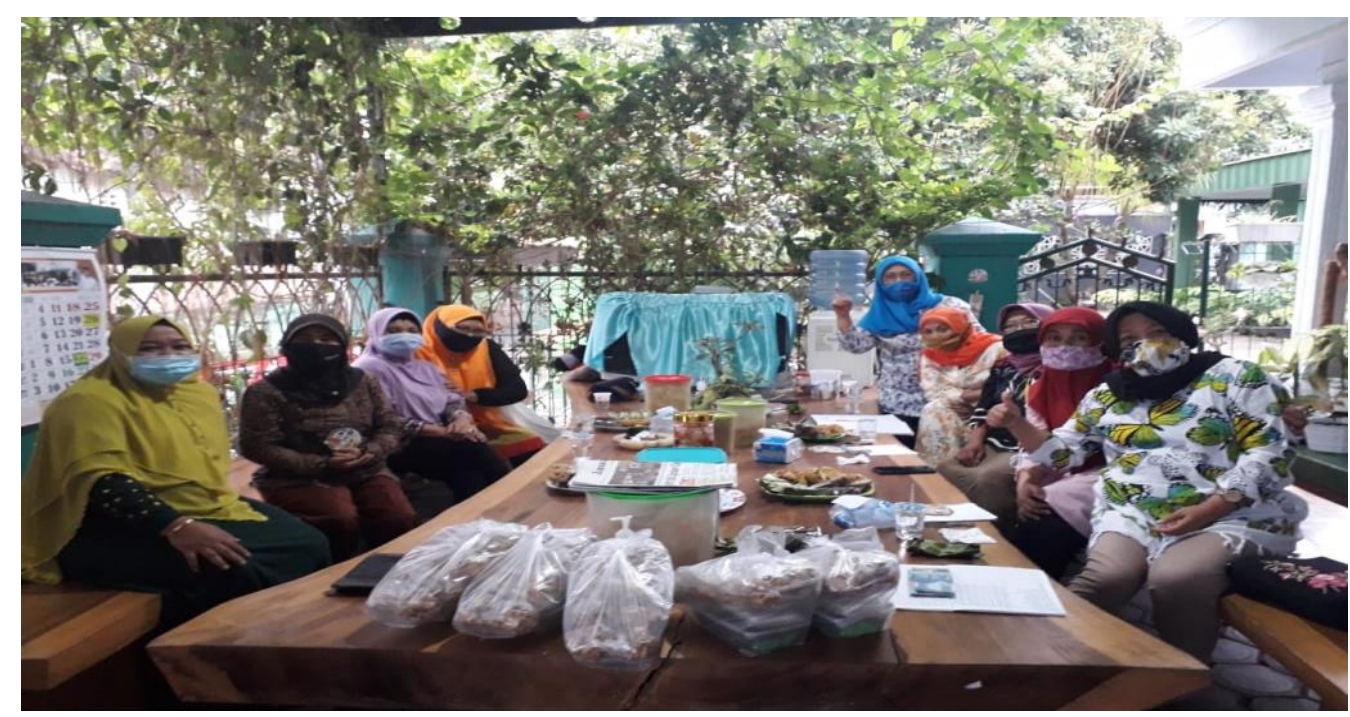

Figure 4. The activities that illustrate the inequality between women and men status from Kepanjen Kidul and Sananwetan Districts

(Wienanda, 2012) and (Witjatmoko, 2016) divides the three stages gap from 0$15 \%$.consider as balance, $16-25 \%$ gap consider to fairly balance, and $>25 \%$ gap is considered as imbalance.

Table 4. Gap and Description

\begin{tabular}{|l|l|c|}
\hline \multicolumn{1}{|c|}{ Categories } & Gap & Description \\
\hline local wisdom belief & $49 \%$ & imbalance \\
\hline social status & $3 \%$ & balance \\
\hline educational background & 37 & imbalance \\
& $\%$ & \\
\hline
\end{tabular}

The table above illustrates the gap in the three categories from female parents who answered the problem formulations in this study: what is the leading cause of the confusion of choosing between local wisdom or recognition of gender equality in spoken language addressing among women with respect to their husbands' titles in their activities?

The main confusion in terms of local wisdom belief results in a $49 \%$ gap, considered imbalance. It illustrates that more than $50 \%$ of female parents and total participants believe in local wisdom in all of their activities. In Javanese custom, women glorify men as leaders in the family to address each other's name by mentioning their husbands' titles in all activities. The second problem, seen from the husband's work's social status, depicts gab 3\%, which is considered balanced. The balance of the number of participants categorized according to husband's occupation illustrates that the husband's identity in their activities is still balanced with their identity, so they often use their names as the identity of their actions. Finally, from an educational background point of view, it depicts a $37 \%$ gap, which is considered imbalanced. Most of the mothers still have lower occupational education than their husbands, so that they always boast of their husband's identity as a family authority in their activities, even they always follow what their parents say without thinking critically.

284 BRILIANT: Jurnal Riset dan Konseptual

Volume 6 Number 2, May 2021 
Previous research has reflected the similarities. Discrepancies and importance to this study's findings are as follows: gender is not an issue in deciding successors; boys and girls are equal, relying on the degree of dedication, obligation, expertise, or incompetency. (Halim, 2017). Culture has a strong influence on country behaviors, including gender discrimination (Vial et al., 2016). Narrower communities currently recognize that few women are represented in the highest ranks. Moreover, social immobility moderates the laurels to which inclusive practices where both sexes are considered equal-section women to develop as leaders. (Toh \& Leonardelli, 2012). The connection between "country" and "femininity" in prominent positions in the patriarchal tribal gold contrasts with Western leadership literature. Thus, despite the disadvantage of feminists in the traditional Arab elite, soul supervisors have described their femininity as a vantage point and superhuman in, among several other things, diminishing ethnic-professional participation marked by a falsity between conventional and demythologized codes, and in attractive on an interpersonal role in the empowerment of Bedouin women in all spheres of life (Quader \& Oplatka, 2008). female power-holders are seen as less legitimate than male power-holders (Vial et al., 2016).

The results present how tribalism and Nomad tariff embedded in the participants' rendering and practices of their religion (along with the existing juristic framework) maintain sexuality gaps in line and positions of a nation. The results also display that despite the Islamic guidelines towards Fairness and justice (haqq and adl) in employment, the tribal and Arabian traditions hold women's work finished patriarchal interpretations of Islam Tamer Koburtay1 · Jawad Syed2 - (Koburtay et al., 2020). although Islamic women proceed to surface a myriad of challenges in the workplace, they can also tackle whatsoever of these issues through their cause strategies and networks, specified as individualized networks and far upbringing (Tariq \& Syed, 2017). There are no gender disparities, and there is no tension between society and gender in the direction of collectivism-individualism and space, puritanism, and supervision-subordinate relationship. The findings of the analysis change the enhancer to the notion that culture affects organizational activities. (Marković et al., 2012). Unable interpersonal norms, laws, and practices work at the heart of gender inequality in the Semite group. Hence, the necessity to be added merged in the MDGs to develop a statesman democratic developmental formulation(Sika, 2011). religious socialization is varied and gendered; men and women are tending and seaworthy to diverge from overriding patriarchal pious interpretations (Glas et al., 2018).

While cultural factors constitute a challenge to Asian women's accounting for elected positions, ethnic factors do not explain the increase in women's descriptive (denotative) status in parliament over the prehistoric two electoral cycles. (Hillman, 2018). Female politicians who are separate from their sexuality were viewed as stable lower qualified, and weaker preferred than an individual whose very name was described as the creator of the macho call. (Dyson, 2000). Women could be chosen as the offspring of ancestral work and point out to someone between women's maturation and success in work stemma trade. (Mathew, 2016). Women's state of government in Crockery has not been substantially improved in the last decades. Women's state's spindled job in the 
cause framework instrument does not contribute to a permanent advance in women's semi-political participation in China (Zeng, 2014).

\section{CONCLUSION}

Calling the father's name on every PKK activity in Blitar is a tradition from ancient times until now. It is believed by them as local wisdom in which men are considered as leaders in the family and are always respected and considered sacred. And on the contrary, women's struggle to equalize the same position as men continues to be encouraged. The understanding of local cultural relations and gender equality above is the right solution to answer the confusion of debates between the two. Harmony in the three aspects of local wisdom belief, social status, and educational background associated with the struggle for gender equality by women is a very good lesson. It is suitable to be applied to all activities of the capital city of Blitar. Therefore, they will have an understanding of addressing habits between their own or husband's titles. It is expected that all mothers in PKK activities use this harmony to interact each other. So that local wisdom that they believe will be maintained and in line with the status of women's equality.

\section{SUGGESTION}

Future researchers are expected to make this study's results as a consideration in problem formulation and make decisions about gender costconstruction that is aligned with local wisdom. And for language and culture teachers, this research will be beneficial as a provision for teaching about the close relationship between feminism and local wisdom in everyday life from children to adults.

\section{REFERENCES}

Booth, C., \& Bennett, C. (2002). Gender mainstreaming in the European Union: Towards a new conception and practice of equal opportunities? European Journal of Women's Studies, 9(4), 430-446. https://doi.org/10.1177/13505068020090040401

Borg, M.D., \& Ghall, W. . (2007). Educational Research: an Introduction (8th ed.). Pearson/Allyn \& Bacon.

Buvinić, M., \& Rao Gupta, G. (1997). Female-headed households and femalemaintained families: Are they worth targeting to reduce poverty in developing countries? Economic Development and Cultural Change, 45(2), 258-280. https://doi.org/10.1086/452273

Craeynest, F. . (2015). Gender Representations in EFL Textbooks: a Quantitative and Qualitative Content Analysis. Ghent University, Ghent, Belgium.

Dahles, H. (2001). Tourism, Heritage and National Culture in Java: Dilemmas of a Local Community. TJ International, Padstow, Cornwall.

Dyson, K. (2000). EMU as Europeanization: Convergence, diversity and contingency. Journal of Common Market Studies, 38(4), 645-666. https://doi.org/10.1111/1468-5965.00258

Echo-hawk, A. R. C., Url, S., \& Echo-hawk, R. C. (2013). Society for American Archaeology Ancient History in the New World: Integrating Oral Traditions and the Archaeological Record in Deep Time All use subject to JSTOR 
Terms and Conditions Ancient History In The New World: Integrating Oral Traditions . 65(2), 267-290.

Eriyanto. (2013). Deskripsi Analisis Wacana, Pengantar Analisis Teks Media. LKIS.

Ernest, P. (1985). The philosophy of mathematics and mathematics education. International Journal of Mathematical Education in Science and Technology, 16(5), 603-612. https://doi.org/10.1080/0020739850160505

Glas, S., Spierings, N., \& Scheepers, P. (2018). Re-Understanding Religion and Support for Gender Equality in Arab Countries. Gender and Society, 32(5), 686-712. https://doi.org/10.1177/0891243218783670

Graves-Brown, P., Jones, S., and Gamble, C. (eds. . (1996). Cultural Identity and Archaeology: the Construction of European Communities. Routledge.

Halim, I. P. (2017). Analisis Persepsi Orang Tionghoa Jawa Timur Terhadap Calon Suksesor Perempuan Pada Perusahaan Keluarga. Agora - Online Graduate Humanities Journal, 5(1).

Hartman, P. L., \& Judd, E. L. (1978). Sexism and TESOL Materials. TESOL Quarterly, 12(4), 383. https://doi.org/10.2307/3586137

Hillman, B. (2018). The Limits of Gender Quotas: Women's Parliamentary Representation in Indonesia. Journal of Contemporary Asia, 48(2), 322-338. https://doi.org/10.1080/00472336.2017.1368092

Holt-Reynolds, D. (1992). Personal History-Based Beliefs as Relevant Prior Knowledge in Course Work. American Educational Research Journal, 29(2), 325-349. https://doi.org/10.3102/00028312029002325

Karskens, G., and Lawrence, S. (2003). The archaeology of cities: What is it we want to know? In Murray, T. (ed.), Exploring the Modern City: Recent Approaches to Urban History and Archaeology, Museum of Sydney.

Klaus Krippendorff. (2004). Content Analysis An Introduction to its Methodology. SAGE Publication Inc.

Koburtay, T., Syed, J., \& Haloub, R. (2020). Implications of Religion, Culture, and Legislation for Gender Equality at Work: Qualitative Insights from Jordan. Journal of Business Ethics, 164(3), 421-436. https://doi.org/10.1007/s10551-018-4036-6

Kohl, P. L., and Fawcett, C. (eds. . (1995). Nationalism, Politics and the Practice of Archaeology. Cambridge University Press.

Kohl, P. L., Kozelsky, M., and Ben-Yehuda, N. (eds. . (2007). Selective Remembrances: Archaeology in the Construction, Commemoration, and Consecration of National Pasts. Chicago University Press.

Lorber, J. (1994). The Social Construction of Gender. SAGE Publication Inc.

Marković, Z., Sardžoska, E., \& Sotiroska, K. (2012). Orientations of the Managers, Culture and Gender: Cross-cultural Study of SupervisorSubordinate Relationship. International Journal of Applied Psychology, 2(5), 104-109. https://doi.org/10.5923/j.ijap.20120205.05

Martin, J. N., \& Nakayama, T. K. (2010). Intercultural communication in contexts (5th ed.). (5th ed.). McGraw-Hill.

Mason, R. J. (2010). Society for American Archaeology Archaeology and Native North American Oral Traditions. American Antiquity, 65(2), 239-266.

Mathew, V. (2016). Women and family business succession in Asia Characteristics, challenges and chauvinism. International Journal of 
Entrepreneurship and Small Business, 27(2-3), 410-424. https://doi.org/10.1504/IJESB.2016.073972

Meskell, L. (ed. . (1998). Archaeology under Fire: Nationalism, Politics and Heritage in the Eastern Mediterranean and Middle East. Routledge.

Mufidah, C. (2017). Complexities in dealing with gender inequality: Muslim women and mosque-based social services in East Java Indonesia. Journal of Indonesian Islam, 11(2), 459-488. https://doi.org/10.15642/JIIS.2017.11.2.459-488

Quader, S. A. R., \& Oplatka, I. (2008). The power of femininity: Exploring the gender and ethnic experiences of Muslim women who accessed supervisory roles in a Bedouin society. Journal of Educational Administration, 46(3), 396-415. https://doi.org/10.1108/09578230810869301

Rees, T. (1998). Mainstreaming Equality in the European Union: Education, Training and Labour Market Policiese. Routledge.

Riyanto, A., Ohoitimur, J., Mulyatno, C. B., \& Madung, O. G. (2015). Kearifan Lokal Pancasila Butir-butir Filsafat Keindonesiaan. Kanisius.

Samovar, L. A., Porter, R. E., McDaniel, E. R., \& Roy, C. S. (2013). Communication between cultures.

Schmidt, P. R. (2006). Historical Archaeology in Africa: Representation, Social Memory, and Oral Traditions. AltaMira.

Schuh, S. C., Hernandez Bark, A. S., Van Quaquebeke, N., Hossiep, R., Frieg, P., \& Van Dick, R. (2014). Gender Differences in Leadership Role Occupancy: The Mediating Role of Power Motivation. Journal of Business Ethics, 120(3), 363-379. https://doi.org/10.1007/s10551-013-1663-9

Schuyler, R. L. (1977). The spoken word, the written word, observed behavior and preserved behavior: The contexts available to the archaeologist. The Conference on Historic Site Archaeology Papers.

Sika, N. (2011). The Millennium Development Goals: Prospects for gender equality in the Arab world. Journal of International Women's Studies, 12(3), 27-42.

Smith, J. C., \& Weisstub, D. N. (2016). The unconscious, myth, and the rule of law: Reflections on the persistence of gender inequality. International Journal of Law and Psychiatry, 48, 62-76. https://doi.org/10.1016/j.ijlp.2016.06.009

Sunderland, J. (2006). Language and Gender: an Advanced Resource Book. Routledge.

Tariq, M., \& Syed, J. (2017). Intersectionality at Work: South Asian Muslim Women's Experiences of Employment and Leadership in the United Kingdom. Sex Roles, 77(7-8), 510-522. https://doi.org/10.1007/s11199-0170741-3

Toh, S. M., \& Leonardelli, G. J. (2012). Cultural constraints on the emergence of women as leaders. Journal of World Business, 47(4), 604-611. https://doi.org/10.1016/j.jwb.2012.01.013

Vial, A. C., Napier, J. L., \& Brescoll, V. L. (2016). A bed of thorns: Female leaders and the self-reinforcing cycle of illegitimacy. Leadership Quarterly, 27(3), 400-414. https://doi.org/10.1016/j.leaqua.2015.12.004

Walby, S. (2001). Gender Mainstreaming in the European Employment Strategy.

Wienanda, W. K. (2012). An Analysis Of Vii Grade English Coursebook Entitled 
English On Sky 1 In Terms Of Gender Balance Of The Materials. Universitas Negeri Malang.

Witjatmoko, N. (2016). Gender Representation in Two EFL Textbooks Used in Grade VII of Junior High School. Universitas Negeri Malang.

Woodward, A. (2003). European Gender Mainstreaming: Promises and Pitfalls of Transformative Policy1. Review of Policy Research, 20(1), 65-88. https://doi.org/10.1111/1541-1338.00005

Yustesia, A. (2018). Concept of Local Wisdom "Barifola " and Implementation of Education Century 21. May 2017.

Zeng, B. (2014). Women's political participation in China: Improved or not? Journal of International Women's Studies, 15(1), 136-150. 